\title{
技術報告
}

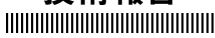

\section{簡易型放射線測定器に利用するための 半導体放射線検出素子の性能評価}

\author{
谷村嘉彦，美留町 厚，吉田 真，渡辺 鐶* \\ 独立行政法人 日本原子力研究開発機構 東海研究開発センター 原子力科学研究所 \\ 319-1195＼cjkstart茨城県那珂郡東海村白方白根 2-4 \\ *名古屋大学 名誉教授 \\ 465-0076 愛知県名古屋市名東区扇町 3-34 \\ 2008 年 7 月 14 日 受理
}

\begin{abstract}
簡易型放射線測定器に利用できる半導体放射線検出素子について, その光子検出性能を校正場で の実測とモンテカルロシミュレーション計算で明らかにした。低価格の検出素子として, Si $p-i-n$ フォトダイオード及び CdTe 検出器を選択した。周辺線量当量 $\mathrm{H}^{*}(10)$ に対するエネルギー特性を $60 \mathrm{keV}$ から $2 \mathrm{MeV}$ のエネルギー領域で評価した。CdTe 検出器はエネルギーの増加とともに感度 が大きく減少することがわかった。一方，Si ダイオードは $150 \mathrm{keV}$ 以上のエネルギーで感度がほ ぼ平坦になるという利点を有する。自然放射線に対する検出素子の感度は, 4 〜 cpm である。放 射線レベルの検出下限レベルを評価したところ，原子力発電所や燃料加工施設などの事故時に放射 線レベルの上昇を把握できることがわかった。
\end{abstract}

Key Words : semiconductor radiation sensor, silicon $\mathrm{p}-\mathrm{i}-\mathrm{n}$ photodiode, CdTe detector, calibration field

\section{1.はじめに}

放射線は，その利用拡大に伴い，一般公衆の 間でも身近な存在になっている。ところが，放 射線を五感で感じることができないため，身の 回りの放射線に関し潜在的に不安感を抱く人が 多い。特にJCO 臨界事故を契機に,こうした 不安感は従来に増して高まってきているものと 推測される。そこで, 住民が身の回りの放射線 レベルを自ら把握し, 判断できる手段を提供す ることは非常に有意義であると考えられる。

身の回りの放射線を把握するためには放射線 測定器が必要となるが, 専門家が使用する高価 な放射線測定器は, 一般家庭で気軽に入手して 測定するには至らない。一方, 比較的安価な放 射線測定器作製キットなども存在するが，その 測定器の安定性や測定された值の持つ意味に関 して明確な保証がない。このため, 性能が十分
に評価された低価格で信頼性の高い簡易型放射 線測定器を開発する必要がある11。

本報告では，簡易型放射線測定器 (以下「簡 易測定器」と呼ぶ）に使用できる 2 種類の半導 体放射線検出素子について，その光子に対する 特性を明らかにした。検出素子の評価では, ト レーサビリティが確保された X 線及び $\gamma$ 線の 校正場を用いた実測と, 検出素子構造を模擬し たシミュレーション計算を利用し，簡易測定器 に使用する上で必要な特性を考察した。

\section{2. 放射線検出素子の選択}

検出素子に求められる要件として, (1) $\gamma$ 線を 検出できること, (2)信号を処理する電子回路を 含めて安価であること，(3)安定に動作すること， (4)自然放射線レベルに対して十分な感度を有す ることなどが挙げられる。また，一般家庭での 使用を考慮すると, 安価で, かつ定期的な点検・ 


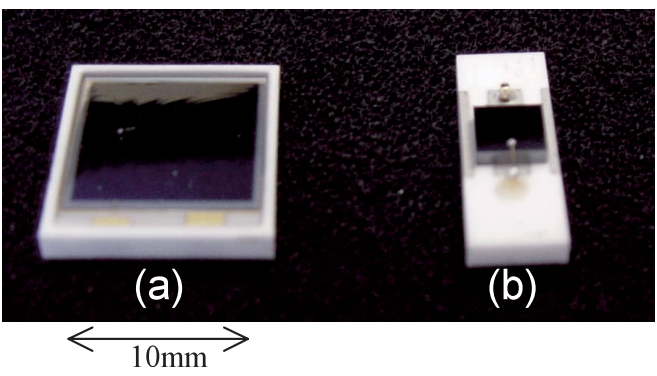

Fig. 1 Photograph of the radiation sensors tested in the present work.

(a) silicon $p$ - $i$ - $n$ photodiode (Hamamatsu S3590-08) (b) CdTe detector (Acrorad $4 \mathrm{~mm}$ $\times 4 \mathrm{~mm} \times 0.5 \mathrm{~mm}^{\mathrm{t}}$ )

調整が簡単であることも重要である。このよう な検出素子として，近年製造の自動化技術が進 み, 経年劣化が少ない半導体素子が有力候補と してあげられる。

上記要件を考慮し, 検出素子として, シリコ ン $p-i-n$ フォトダイオード（以下「Si ダイオー ド」と呼ぶ）及び $\mathrm{CdTe}$ 検出器を選択した。

これらの検出素子の外観写真を Fig. 1 に示す。

$\mathrm{Si}$ ダイオードは, 本来, 光検出器として用 いられるが，電離放射線に感度があり，放射線 の検出素子として用いることができる。光検出 器として, 量産技術は十分に確立しており, 大 量生産により価格の低減が期待できる。本報告 においては, 光検出器としては比較的大きい有 感部分面積 $(10 \mathrm{~mm} \times 10 \mathrm{~mm})$ を有する浜松ホ トニクス製 S3590-08 を評価対象とした。静電 容量より計算した有感領域の厚さは, 約 270 $\mu \mathrm{m}$ である。

$\mathrm{CdTe}$ 検出器は, テルル化カドミウム (CdTe) 単結晶を利用した検出素子であり，比較的高い 原子番号を持つため, 寸法が小さくても光子に 対する感度が大きいことが期待できる。近年, 良好な単結晶製造技術が確立され, 低価格化が 進んでいる ${ }^{2)}$ 。本報告においては, CdTe 検出 器として，アクロラド製の結晶形状が $4 \mathrm{~mm} \times$ $4 \mathrm{~mm} \times 0.5 \mathrm{~mm}^{\mathrm{t}}$ の素子を選択して特性を評価 した。

\section{3. 評 価方 法}

$3 \cdot 1$ 基準校正場を用いた実験

上述の 2 種類の検出素子について, 日本原子 力研究開発機構 放射線標準施設棟で $X$ 線発生 装置及び $\gamma$ 線源を用いた基準照射試験を行 い, $70 \mathrm{keV}$ から $1.3 \mathrm{MeV}$ の光子エネルギー範 囲で応答特性を調べた。

検出素子の X 線照射試験については，国家 標準場で校正された電離箱を使用して，基準照 射線量率を決定した ${ }^{3), 4)}$ 。 $\gamma$ 線の照射試験には ${ }^{51} \mathrm{Cr},{ }^{137} \mathrm{Cs}$ 及び ${ }^{60} \mathrm{Co}$ 線源を用い，国家標準場 で校正された電離箱で基準線量率が評価されて いる $320 \mathrm{keV}, 662 \mathrm{keV}$ 及び $1.25 \mathrm{MeV}$ の 3 種 類の $\gamma$ 線エネルギーについて照射を行った ${ }^{4)}$ 。

検出素子からの信号パルスをプリアンプ及び 主増幅器で増幅した後, 多重波高分析器に入力 して波高分布を測定した。波高弁別レベルを設 けて，そのレベルを超えた信号の計数率を計算 し，照射時の基準線量当量率で割ることにより 線量当量あたりの感度を求めた。本測定では, ノイズなどの影響が無視できる $50 \mathrm{keV} に$ 波高 弁別レベルを設定した。試験時の線量当量率は, $\mathrm{X}$ 線照射時では $20 \sim 400 \mu \mathrm{Sv} \mathrm{h}^{-1},{ }^{137} \mathrm{Cs}$ 及び ${ }^{60} \mathrm{Co}$ 線源では $100 \mu \mathrm{Sv} \mathrm{h}{ }^{-1},{ }^{51} \mathrm{Cr}$ 線源では 30 $\mu \mathrm{Sv} \mathrm{h}^{-1}$ とした。

$3 \cdot 2$ モンテカルロシミュレーション計算に よる評価

実測で検出素子の特性試験を行う場合, 使用 する線源が限られるため, 決められたエネルギ 一での評価しかできない。このため, 検出素子 の構造をできるだけ正確に模擬したモンテカル ロシミュレーション計算を行い, 実測が不可能 なエネルギー領域の特性を評価した。計算結果 の妥当性は, 実測と比較することにより検証し た。シミュレーション計算には, 中性子・光子 輸送モンテカルロコード MCNP-4C を用いた5)。

$\mathrm{Si}$ ダイオードでは, シリコン基板内の空そ 層を有感領域とした。また, 表面酸化膜, 電極, 


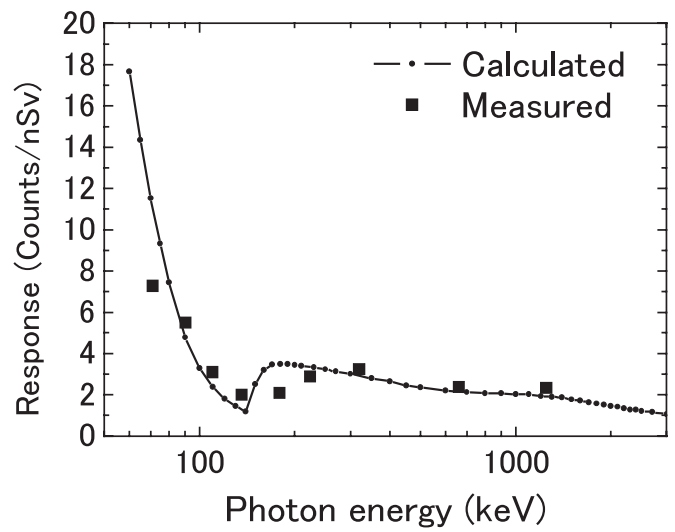

Fig. 2 Responses of silicon $p-i-n$ photodiode measured in photon calibration fields and calculated by using MCNP-4C code.

シリコン基板，表面保護用のエポキシ保護層， アルミナパッケージ, 回路用プリント基板, 遮 光用テフロンテープ, 電磁シールド用アルミニ ウムケースを考慮し，計算体系に入力した。 CdTe 検出器については, CdTe 単結晶全体を 有感領域とした。また, 結晶固定用アルミナ基 板，電磁シールド用の鉄製ケースを考慮した。

作成した検出素子の計算体系に, $60 \mathrm{keV} \sim 2$ $\mathrm{MeV}$ までの単色の光子を入射させて, 有感領 域内に付与されたエネルギーの分布を計算した。 光子を平行ビームとして, $\mathrm{Si}$ ダイオード及び CdTe 検出器の電極面に垂直に入射させた。

入射光子のエネルギーごとに, 付与されたエ ネルギーが実験と同じ $50 \mathrm{keV}$ を超える事象を 計数し, 入射光子の周辺線量当量 $\mathrm{H}^{*}(10)$ で除
すことにより，線量当量あたりの感度を計算し た。光子フルエンスから線量当量への計算には ICRP $74^{6)}$ に記載されている換算係数を利用した。

\section{4. 結果及び考察}

$4 \cdot 1$ 検出素子のエネルギー特性

$\mathrm{Si}$ ダイオードについて, 実測及び計算で求 めた線量当量あたりの計数と入射光子エネルギ 一の関係を Fig. 2 に示す。全体的な傾向は実 測と計算で比較的良く一致している。

$100 \sim 150 \mathrm{keV}$ 付近で感度が急に低下する領 域が観測される。この原因として, 以下の二つ の効果が考えられる。(1)光子エネルギーの増加 に伴い光電効果の相互作用確率が減少するため, 感度が低下する。(2)光子エネルギーが $140 \mathrm{keV}$ を超えると，コンプトン端が波高弁別レベルの $50 \mathrm{keV}$ よ大きくなり，コンプトン散乱によ る信号が計数されるため, 感度が上昇する。こ れらの効果が組み合わされることにより, 感度 が低下し，再び向上するという特異な傾向が観 測される。また, $\mathrm{Si}$ ダイオードの場合, 入射 光子のエネルギーが高くなってもそれほど感度 は減少しない。特に, $150 \mathrm{keV}$ 以上では線量当 量あたりの感度はほぼ一定である。この原因を 明らかにするために，MCNP-4Cコードにより， 有感領域内に二次電子が入射した場合の光子及 び二次電子の挙動を視覚化した。 $300 \mathrm{keV}$ 及び $2 \mathrm{MeV}$ の入射光子エネルギーに対して計算し た結果を Fig. 3 に示す。図中の赤色で示した

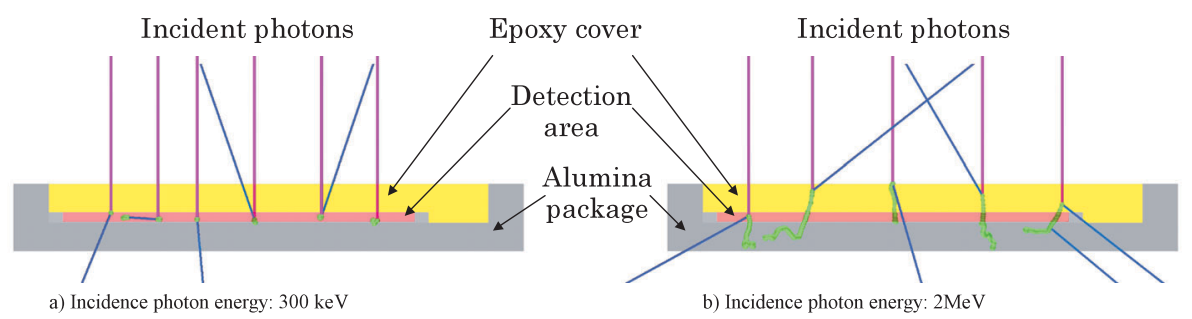

Fig. 3 Illustration of photon interactions and secondary electron tracks inside the silicon $p-i-n$ photodiode, based on the simulation with MCNP-4C. The incident photons, the secondary electron and secondary photons, which include Compton scattered and bremsstrahlung photons, are colored by magenta, green and blue, respectively. 
領域は有感層，黄色はエポキシ保護層，灰色は アルミナパッケージを表している。入射光子， 散乱光子（コンプトン散乱及び制動放射）及び 電子の飛跡を，それぞれ，赤紫色，青色及び緑 色で示す。 $100 \mathrm{keV}$ 以上の入射光子エネルギー では，エポキシ樹脂中ではコンプトン散乱が支 配的になり，二次電子として主にコンプトン電 子が生成される。エポキシ保護層内で大角散乱 により生成されたコンプトン電子は, 入射光子 エネルギーが $300 \mathrm{keV} ， 1 \mathrm{MeV}$ 及び $2 \mathrm{MeV}$ の

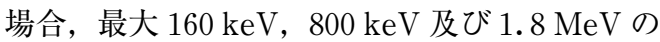
エネルギーを有する。この最大エネルギーとな るコンプトン電子のエポキシ樹脂中の飛程は, それぞれ， $0.18 \mathrm{~mm}, 1.9 \mathrm{~mm}$ 及び $5.6 \mathrm{~mm}$ と なり, エポキシ保護層を透過して有感領域に達 する。このため, 光子エネルギーが高くなると， 信号の生成に寄与する電子の発生領域が大きく なり, $150 \mathrm{keV}$ 以上の入射光子エネルギーでは 感度の低下が緩やかになると考えられる。

$\mathrm{CdTe}$ 検出器について，実測及び計算で得ら れた線量当量あたりの計数と入射光子エネルギ 一の関係を Fig. 4 に示す。図中には，比較の ためにSi ダイオードの計算結果を示している。 全体的な傾向は, $\mathrm{Si}$ ダイオードの場合と同様 に，実測と計算で概ね一致している。

入射光子エネルギーが高くなるに従って，

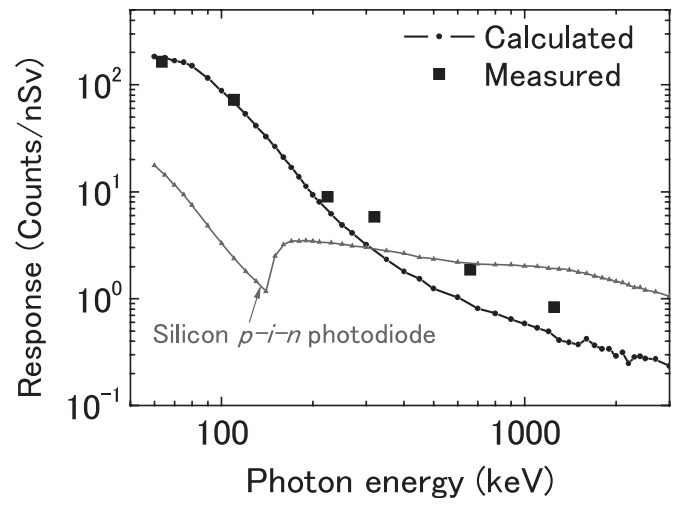

Fig. 4 Responses of CdTe detector measured in the photon calibration fields and calculated by using MCNP-4C code, accompanied with those of the silicon $p-i-n$ photodiode.
$2 \sim 3$ 桁と急激に感度が減少し，エネルギー依 存性があまり良くないことがわかる。これは， CdTe 結晶はシリコンと比べて原子番号が高く, 高エネルギー領域においてもシリコンより光電 効果の発生確率が相対的に高くなるためである と考えられる。

\section{$4 \cdot 2$ 検出素子の感度特性の比較}

Fig. 4 に示すように, Si ダイオードの感度 は， $150 \mathrm{keV}$ 以上のエネルギーでは線量当量に 対してほぼ一定となる。この特性は, 線量当量 率を表示する簡易測定器には適している。一方, 小さな素子の $\mathrm{CdTe}$ 検出器は, 低エネルギー で高い感度が得られるが，高エネルギーでは感 度が急激に減少する。このため, 線量当量率を 測定するためには，エネルギー依存性を補償す る特別な工夫が必要となる。

これらの検出素子が，自然放射線の存在を知 覚できる感度を有しているか，また，放射線し ベルが異常に上昇した際に，どの程度その異常 を検知できるかを確認した。まず，鉄筋コンク リート建家内において自然放射線を測定した。 その結果, Si ダイオード及び CdTe 検出器に おいて，それぞれ，4 cpm 及び $6 \mathrm{cpm} の$ 計数 率が得られた。これは，自然放射線の存在を知 覚するには十分な計数率である。

次に，それぞれの検出素子について，有意に 上昇したと判定できる放射線レベルの下限值 （以下「検出下限レベル」と呼ぶ）を求め，原 子力災害時などの線量基準值と比較した。検出 下限レベルの評価には，各検出素子の 4 分間の 積算計数を利用することとした。自然放射線の 計数に対して，その標準偏差の 3 倍を平常の変 動幅とし，それを超える計数が得られた時の放 射線レベルを検出下限レベルとした ${ }^{7)}$ 。原子力 発電所の重大事故時に放出が予測される気体状 物質として，放射性希ガス，放射性ヨウ素など が挙げられる ${ }^{8)}$ 。上記核種のうち，低，中及び 高エネルギーの $\gamma$ 線を放出する核種として, ${ }^{133} \mathrm{Xe}(81 \mathrm{keV}) ，{ }^{132} \mathrm{I}(667 \mathrm{keV})$ 及び ${ }^{135} \mathrm{I}(1.26$ 
Table 1 Background count and detection limit for photon energies of $80 \mathrm{keV}, 662 \mathrm{keV}$ and $1.25 \mathrm{MeV}$

\begin{tabular}{|c|c|c|c|c|}
\hline \multirow{2}{*}{ Radiation sensor } & \multirow{2}{*}{$\begin{array}{l}\text { B.G. count } \\
\text { (in } 4 \text { min) }\end{array}$} & \multicolumn{3}{|c|}{ Detection limit $^{* *}\left(\mu \mathrm{Sv} \mathrm{h}^{-1}\right)$} \\
\hline & & Photon energy/ $80 \mathrm{keV}$ & $662 \mathrm{keV}$ & $1.25 \mathrm{MeV}$ \\
\hline $\begin{array}{c}\text { Silicon } \\
p-i-n \text { photodiode }\end{array}$ & 16.7 & 0.1 & 0.2 & 0.2 \\
\hline CdTe detector & 23.5 & 0.04 & 0.3 & 0.7 \\
\hline
\end{tabular}

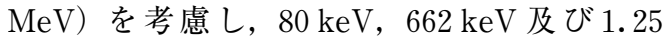
$\mathrm{MeV}$ 光子について，それぞれの検出下限レベ ルを算出した。 $80 \mathrm{keV}$ 光子については計算に よる感度を， $662 \mathrm{keV}$ 及び $1.25 \mathrm{MeV}$ 光子につ いては ${ }^{137} \mathrm{Cs}$ 及び ${ }^{60} \mathrm{Co} て ゙$ 校正した感度を利用し た。各検出素子について導出した検出下限レベ ルを Table 1 に示す。自然放射線レベルは数十 から百数十 $\mathrm{nSv} \mathrm{h} \mathrm{h}^{-1}$ であり, その数倍から 1 桁 程度高い放射線レベルであれば異常を検知でき

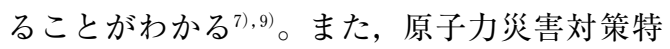
別措置法では，原子力事業者の通報基準として， 原子力事業所境界付近で $5 \mu \mathrm{Sv} \mathrm{h}^{-1}$ という線量 当量率を設定している。Table 1 で評価した数 值はいずれもこれを 1 桁程度下回っており, 緊 急時に大まかな放射線レベルを把握するという 目的では, 検出素子として十分な感度を有する ことがわかる。

\section{5. まと め}

一般家庭でも使用できる簡易測定器に利用可 能な放射線検出素子として $\mathrm{Si}$ ダイオード及び CdTe 検出器を取り上げ，それらのエネルギー 特性を実測と計算により詳細に評価した。その 結果, Si ダイオードは, 低エネルギーで感度 が上昇するが， $150 \mathrm{keV}$ 以上では線量当量に対 して平坦な感度を有することが明らかになった。 $\mathrm{CdTe}$ 検出器については, 原子番号が高く, 小 さい結晶で高感度が得られるが，エネルギーの 増加とともに感度が急激に減少するため, エネ ルギー補償などの工夫が必要であることがわか った。いずれの検出素子も, 自然放射線を知覚
するには十分な感度を有しており，また，原子 力災害時に放射線レベルの異常の有無を確認で きる感度を有することが確認された。しかし， エネルギー特性, 自然放射線に対する感度など を考慮すると, 簡易測定器に利用するには $\mathrm{Si}$ ダイオードが適していると考えられる。

\section{謝 辞}

本研究を進めるにあたり，多岐にわたりご指 導を頂いた森 千鶴夫名古屋大学名誉教授に心 より感謝いたします。また，自然放射線及び緊 急時の放射線レベル測定について，ご指導を頂 いた原子力科学研究所 放射線管理部 堤 正博 氏並びに大石哲也氏に感謝いたします。

\section{文献}

1）谷村嘉彦, 美留町 厚, 低価格・ハンディ型の 簡易放射線メー夕, 月刊エネルギーレビュー, 318 (第 27 巻第 7 号), 25-27 (2007)

2) 大野良一, CdTe 系放射線検出器の開発動向, 放射線，30,23-32(2004)

3）清水 滋, 高橋史明, 澤畠忠広, 當波弘一, 菊 池 寛, 村山 卓, 放射線測定器の性能試験に 用いる X 線校正場の特性評価, JAERI-Tech 99004 (1999)

4) Yoshizawa, M., Shimizu, S., Kajimoto, Y., Kawasaki, T., Fujii, K., Saegusa, J., Tanimura, Y. and Yamamoto, H., Present Status of Calibration Facility of JAERI-Facility of Radiation Standards -, Proceedings of IRPA 11, 3b46 (2004)

5) Briesmeister, J. F.(Ed.), MCNP-A General Monte Carlo N-Particle Transport Code, version 4C, LA-13709-M, Los Alamos National Labora- 
tory (2000)

6) International Comission on Radiological Protection, Conversion Coefficients for Use in Radiological Protection Against External Radiation, ICRP Publ. 74 (1995)

7）原子力安全委員会，環境放射線モニタリング指 針, 平成 20 年 3 月改訂 (2008)

8) Saito, K. and Moriuchi, S., Conversion Factors for Estimating Release Rate of Gaseous Radioactivity by an Aerial Survey, JAERI-M 88-016 (1988)

9）日本分析センター，環境放射線データベース, http : //search.kankyo-hoshano.go.jp/

\section{Abstract}

Performance of Semiconductor Radiation Sensors for Simple and Low-cost Radiation Detector

Yoshihiko TANIMURA, Atsushi BIRUMACHI, Makoto YoshidA and Tamaki WATANABE*: Nuclear Science Research Institute, Tokai Research and Development Center, Japan Atomic Energy Agency, 2-4 Shirakata-
Shirane, Tokai-mura, Naka-gun, Ibaraki Pref. 319-1195, Japan, *Professor emeritus of Nagoya University, 334 Ougimachi, Meito-ku, Nagoya-shi, Aichi Pref. 4650076, Japan

In order to develop a simple but reliable radiation detector for the general public, photon detection performances of radiation sensors have been studied in photon calibration fields and by Monte Carlo simulations. A silicon $p-i-n$ photodiode and a $\mathrm{CdTe}$ detector were selected for the low cost sensors. Their energy responses to ambient dose equivalent $\mathrm{H}^{*}(10)$ were evaluated over the energy range from $60 \mathrm{keV}$ to $2 \mathrm{MeV}$. The response of the $\mathrm{CdTe}$ decreases markedly with increasing photon energy. On the other hand, the photodiode has the advantage of almost flat response above $150 \mathrm{keV}$. The sensitivities of these sensors are 4 to $6 \mathrm{cpm}$ for the natural radiation. Detection limits of the radiation level are low enough to know the extreme increase of radiation due to emergency situations of nuclear power plants, fuel treatment facilities and so on.

(Received July 14, 2008) 